\title{
APP_081 Association of Hematuria on Microscopic Urinalysis and Risk of Urinary Tract Cancer Development
}

\section{Kaiser Permanente Los Angeles Medical Center}

Howard Jung, Joseph Gleason, Ronald Loo, Hetal Patel, Jeff Slezak, Gary Chien, Steven Jacobsen

Introduction and Objective

The American Urological Association (AUA) recommends evaluation for urinary tract cancer in a patient with hematuria $(>3$ $\mathrm{RBC} / \mathrm{HPF}$ ). Meanwhile, the Canadian Urological Association (CUA) recommends evaluation only if the patient is $>40$ years old. The purpose of this study is to determine the incidence of urinary tract cancer in patients with hematuria, and to examine best policy recommendations.

Methods

This is a retrospective cohort study including all members in a health maintenance organization with hematuria diagnosed from January 1, 2004 to December 31, 2005. The primary outcome was the diagnosis of urinary tract malignancy by December 31, 2008.

Results

The cohort includes 156,691 members with one urinalysis demonstrating hematuria. There were 1,353 urinary tract cancers in the group. Of them, 1,071 demonstrated hematuria. Urinary tract cancer rates were associated with older age, higher degree of hematuria, and male sex. Using the AUA recommendations, we calculated a sensitivity of $50.2 \%$, specificity of $83.8 \%$, and positive predictive value (PPV) of $1.3 \%$. Using the CUA recommendations, we calculated a sensitivity of $49.2 \%$, specificity of $88.4 \%$, and PPV of $1.8 \%$. Using an alternative cutoff of $>25 \mathrm{RBC} / \mathrm{HPF}$ in members $>40$, we calculated a sensitivity of $50.4 \%$, specificity of $92.2 \%$, and PPV of $2.8 \%$.

Conclusions

Current recommendations for the evaluation of hematuria yield low rates of cancer detection. We need an alternative policy to improve identification of patients at risk of developing urinary tract cancer.

\section{APP-082 膀胱尿管逆流症に伴う腎瘏痕形成に対する尿中 NGAL を用いた非侵襲的なバイオマーカーとして の有用性に関する検討}

\section{藤田保健衛生大学医学部腎泌尿器外科学1), 藤田保健衛生大学医学部小児科学 ${ }^{2)}$, 藤田保健衛生大学総合医科学研究 所分子遺伝学 ${ }^{3)}$, 東邦大学医学部小児腎臓学4)}

市野 学 ${ }^{1)}$, 日下 守 ${ }^{1)}$, 畔柳 陽子 ${ }^{1.3)}$, 森 輝実 ${ }^{3)}$, 諸岡 正史 ${ }^{2)}$, 佐々木 ひと美 ${ }^{1)}$, 白木 良一 ${ }^{1)}$, 宍戸 清一郎 ${ }^{4)}$, 倉橋 浩樹 ${ }^{3}$, 星長 清隆 1 )

【緒言】膀胱尿管逆流症（VUR）に伴う逆流性腎症により形成される腎瘏痕は、小愳腎不全の原因疾患として重要である。手術適応を決定するため

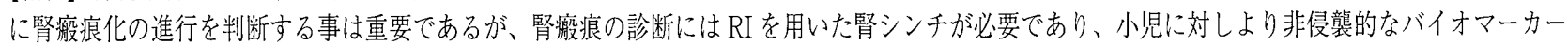
の開発が期待される。【目的】我々は本研究の基礎研究としてラット腎㾮痕モデルを作成し、腎疲痕形成に関わる遺伝子の網羅的解析を行った結果、 バイオマーカーの候補遺伝子として発現の持続㐫進が認められる neutrophil gelatinase-associated lipocalin (NGAL) に着目した。次いで同モデル を用いて尿中 NGALを検討したところ、腎瘢痕のバイオマーカーとしての有用性が示唆された。今回 VUR患児の尿を用いて尿中 NGALが腎瘏痕 の簡便で非侵襲的なバイオマーカーとして有用性について検討した。【方法】対象は2006 年 4 月から 2008 年 3 月までにVURと診断された 34 症例 (54 尿管)。年齢は 5 力月から 11 歳 7 力月。男児 26 例、女览 8 例。VUR grade は I 度 3 例 $\cdot$ II 度 13 例 · III 度 19 例 $\cdot$ IV 度 17 例 $\cdot V$ 度 2 例。 3 力 月以内に尿路感染症を併発した患者は除外した。Control 群として、正常児 28 例について同様に検討した。年齢は 3 力から 9 歳。男児 14 例、女 児 14 例。尿中NGALの測定はNGAL ELISA Kit（BioPorto Diagnostics、Gentofte、Denmark）を用いた。㭘討項目として 1:VUR 群とControl 群 における尿中 NGAL の比較。2: 尿中 NGALの grade 分類別の検討。3:renal scarring 群 (RS 群) と no renal scarring 群 (NRS 群) に分類し、尿 中 NGAL、尿中 beta2-microglobulin (BMG)、尿中N-acetyl-D-glucosaminidase (NAG)、血清クレアチニン（Cr）各々について比較検討した。尿 中 NGAL は尿中 BMGとNAGとともに尿中Crで補正した。統計学的解析には Student's t-test と one-way analysis of variance (ANOVA) を用 いた。結果】24例で99mTc-DMSA 腎シンチが施行された。Control群で正常児の尿中NGALを測定し、年齢に伴う正常曲線を作製した。( $=161.8 \mathrm{x}^{0.85}$, $\left.\mathrm{R}^{2}=0.416, \mathrm{P}<0.0001\right)$ 男女差はなく、新生児ほど高く、1歳までに急激に低下しその後安定した。以後の結果は全てこの正常曲線を用いて補正し

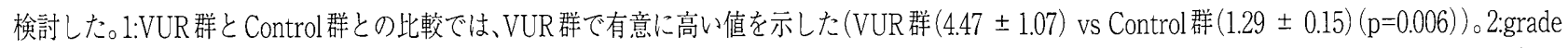

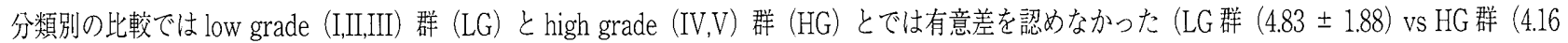
$\pm 1.20)$ ）。3: 尿中 NGALはRS 群 $(6.58 \pm 1.76)$ とRS 群 $(0.68 \pm 0.12)$ で有意差を認めた（ $\mathrm{p}=0.004 ）$ 。cut off 值を 1.0 とすると感度 $89.5 \%$ 、特異 度 $100 \%$ あっった。尿中 BMG と尿中 NAG と血清Cr 值は両群で有意差を認めなかった。結語】VURならびに腎洀痕形成における NGAL発現の 機序は未だ不明であるが、尿中 NGALは非侵襲的な腎痏痕のバイオマーカーとして有用である可能性が示㖫された。 